\title{
Effects of caffeine on learning and memory in rats tested in the Morris water maze
}

M.E.M. Angelucci ${ }^{1,2}$, C. Cesário ${ }^{1}$, R.H. Hiroi ${ }^{1}$, P.L. Rosalen ${ }^{2}$ and C. Da Cunha ${ }^{1}$

\author{
${ }^{1}$ Laboratório de Fisiologia e Farmacologia do Sistema Nervoso Central, \\ Departamento de Farmacologia, Universidade Federal do Paraná, Curitiba, PR, Brasil \\ ${ }^{2}$ Faculdade de $\mathrm{O}$ dontologia de Piracicaba, Universidade Estadual de Campinas, \\ Piracicaba, SP, Brasil
}

\section{Correspondence \\ C. Da Cunha \\ Laboratório de Fisiologia e \\ Farmacologia do SNC \\ Departamento de Farmacologia, \\ UFPR \\ 81531-990 Curitiba, PR \\ Brasil \\ Fax: $+55-41-266-2042$ \\ E-mail: dacunha@bio.ufpr.br.}

Research supported by CNPq.

Publication supported by FAPESP.

Received March 8, 2002

Accepted June 24, 2002

\section{Abstract}

We studied some of the characteristics of the improving effect of the non-specific adenosine receptor antagonist, caffeine, using an animal model of learning and memory. Groups of 12 adult male Wistar rats receiving caffeine $(0.3-30 \mathrm{mg} / \mathrm{kg}$, ip, in $0.1 \mathrm{ml} / 100 \mathrm{~g}$ body weight) administered $30 \mathrm{~min}$ before training, immediately after training, or 30 min before the test session were tested in the spatial version of the Morris water maze task. Post-training administration of caffeine improved memory retention at the doses of $0.3-10 \mathrm{mg} / \mathrm{kg}$ (the rats swam up to $600 \mathrm{~cm}$ less to find the platform in the test session, $\mathrm{P} \leq 0.05$ ) but not at the dose of $30 \mathrm{mg} / \mathrm{kg}$. Pre-test caffeine administration also caused a small increase in memory retrieval (the escape path of the rats was up to $500 \mathrm{~cm}$ shorter, $\mathrm{P} \leq 0.05$ ). In contrast, pre-training caffeine administration did not alter the performance of the animals either in the training or in the test session. These data provide evidence that caffeine improves memory retention but not memory acquisition, explaining some discrepancies among reports in the literature.
Key words

- Memory

- Learning

- Caffeine

- Methylxanthines

- Adenosine receptor antagonist

- Morris water maze

\section{Introduction}

Methylxanthine caffeine, present in many common beverages, is among the psychostimulant drugs more extensively consumed by the world population (1). Besides having a stimulant effect on the heart and respiratory system, caffeine also presents numerous behavioral stimulant effects. It has weak reinforcing properties inducing self-administration both in humans and non-human primates (2). Moderate doses of caffeine induce behavioral stimulant effects that suggest CNS stimulation but higher doses can suppress behavioral activity and even performances associated with learning and memory (1).

There are many reports showing that caffeine may ameliorate amnesia in human beings, particularly in cases of age-related cognitive decline (3), scopolamine-induced amnesia (4), and electroconvulsive therapy $(5,6)$. Many of these studies with human subjects are not specifically addressed to memory issues $(5,7)$ and interpretations of the results may be difficult due to interference of the previous caffeine consumption habits and heterogeneity of the samples. The improving effect of caffeine on animal models of learning and memory has been reported since the 1960 's $(8,9)$ but the results of these animal 
studies are also contradictory. We recently published a study reporting that the effect of caffeine on two other memory tasks depends on the schedule of administration. Depending on whether it is administered pre-training or post-training it can impair or improve memory, respectively (10). Now we extend this investigation by studying the effect of caffeine on the spatial version of the Morris water maze.

\section{Material and Methods}

\section{Animals}

Adult male Wistar rats (240-300 g) from our own breeding stock were used. The animals were maintained in a temperature-controlled room $\left(22 \pm 2^{\circ} \mathrm{C}\right)$ on a 12-h light/dark cycle (lights on at 7:00 am) with food and water available ad libitum. All the behavioral experiments were conducted between 13:00 and 18:00 $\mathrm{h}$. The animals were maintained in Plexiglas home cages $(60$ × 25 × 25 $\mathrm{cm}$ ), and the same five cagemate rats were maintained until the end of the experiments.

The rats were divided into 13 groups of 12 animals each. Caffeine (Sigma, St. Louis, MO, USA) was dissolved in saline $(0.9 \%$ $\mathrm{NaCl}$ ) and administered $i p$ in a volume of 0.1 $\mathrm{ml} / 100 \mathrm{~g}$ body weight. In the first experiment, groups of animals received saline or 3 , 10 , or $30 \mathrm{mg} / \mathrm{kg}$ caffeine $30 \mathrm{~min}$ before the water maze training session (see below). In the second experiment, groups of animals received saline or $0.3,3,10$, or $30 \mathrm{mg} / \mathrm{kg}$ caffeine immediately after the training session. In the third experiment, groups of animals received saline or 3,10 , or $30 \mathrm{mg} / \mathrm{kg}$ caffeine, $30 \mathrm{~min}$ before the test session.

\section{Behavioral procedures}

A modification of the spatial version of the water maze task described by Morris et al. (11) was used. The water maze consisted of a round tank $170 \mathrm{~cm}$ in diameter and 70 $\mathrm{cm}$ deep, filled with water. The water temperature was maintained at $25^{\circ} \mathrm{C}$. A platform $(11 \times 14 \mathrm{~cm})$ submersed $2 \mathrm{~cm}$ under the water surface was placed on the center of one of the four imaginary quadrants of the tank and maintained in the same position during all trials. Several distal visual cues were placed on the walls of the water maze room. During the experiments, the tank was videotaped and the scores for latency to escape to the platform, distance traveled from the starting point to the platform, and the swimming speed were later computed. An image analyzer (CEFET, Curitiba, PR, Brazil) was used to measure the distance traveled and the swimming speed of the rats in the pool. The training session consisted of four consecutive trials during which the animals were left in the tank facing the wall, and allowed to swim freely to the escape platform. If the animal did not find the platform in $120 \mathrm{~s}$ it was gently guided to it. The animal was allowed to remain on the platform for $10 \mathrm{~s}$ after escaping to it and was then removed from the tank for $20 \mathrm{~s}$ before being placed at the next starting point in the tank. This procedure was repeated six times, with the starting points (the axis of one imaginary quadrant) varying in a pseudo-randomized manner. The test session was performed $48 \mathrm{~h}$ later and was similar to the training session, except that the number of trials was reduced to three.

\section{Statistical analysis}

Data from the training and test sessions were analyzed separately by two-way ANOVA taking the number of the trial as a repeated measure. Differences between groups were evaluated by the post hoc Duncan test.

\section{Results}

Figure 1 shows the results obtained when caffeine was administered 30 min before the 
training session. In the training session all groups learned to reach the platform $(\mathrm{P} \leq 0.001)$. Treatment with caffeine did not affect the training scores $(\mathrm{P} \geq 0.2$ for treatment and for interaction treatment $v s$ repeated measure). Pre-training caffeine administration also did not affect retention (test session) scores $(\mathrm{P} \geq 0.2)$.

Figure 2 shows the effect of caffeine treatment on swimming speed. Two-way ANOVA showed that speed increased as a function of the number of trials $(\mathrm{P} \leq 0.001)$ but was not affected by treatment $(\mathrm{P} \geq 0.2)$. In spite of the lack of effect, there was a significant interaction between caffeine treatment and the repeated measure $(\mathrm{P} \leq 0.05)$.

The effect of post-training administration of caffeine immediately after the training session is presented in Figure 3. In the training session groups learned to reach the platform $(\mathrm{P} \leq 0.001)$. In the training session the groups did not differ in the training scores for latency to reach the platform (latency: $\mathrm{F}(4,55)=0.65, \mathrm{P} \geq 0.2$; traveled distance: $\mathrm{P}=$ $0.10)$. Analysis of the test session scores showed that $0.3-10 \mathrm{mg} / \mathrm{kg}$ caffeine improved retention when administered immediately after the training session: repeated measure (session trial), latency or traveled distance: $\mathrm{P} \leq 0.001$; treatment, latency: $\mathrm{P} \leq 0.05$; treatment, traveled distance: $\mathrm{P}=0.18$; interaction treatment $v s$ repeated measure, latency: $\mathrm{P} \leq 0.01$; interaction treatment $v s$ repeated measure, traveled distance: $\mathrm{P} \leq 0.05$. The highest improving effect was observed with the administration of the lower doses $(\mathrm{P} \leq 0.05$, post hoc Duncan test) whereas the dose of 30 $\mathrm{mg} / \mathrm{kg}$ had no effect $(\mathrm{P}=0.14$, post hoc Duncan test). Traveled distance data showed a significant difference only at the dose of $0.3 \mathrm{mg} / \mathrm{kg}$.

Figure 4 shows the results obtained with the administration of caffeine $30 \mathrm{~min}$ before the test session. In the training session the groups learned to reach the platform $(\mathrm{P} \leq 0.001)$. In the training session the groups did not differ in the training scores for la-
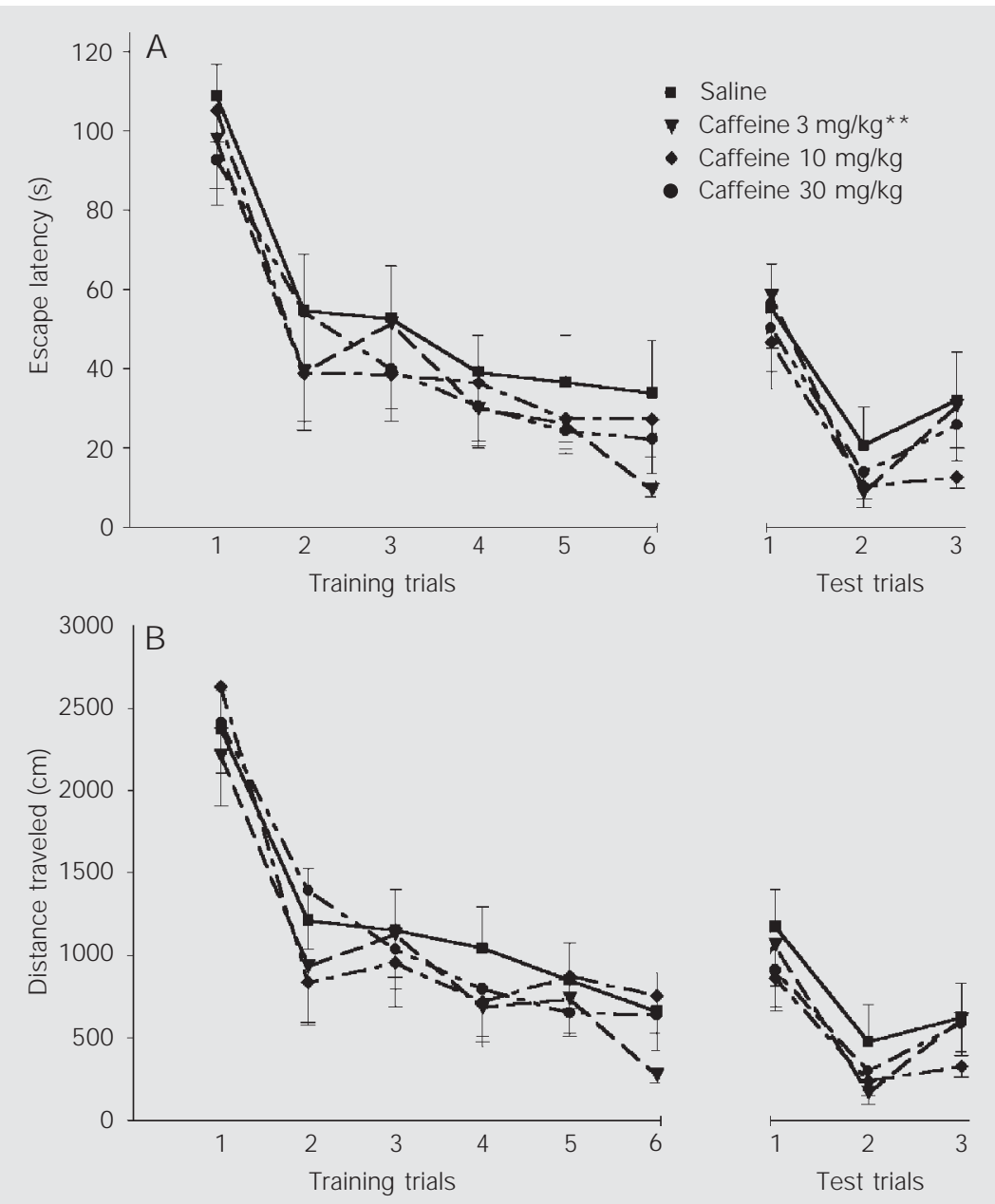

Figure 1. Effect of the administration of caffeine 30 min before the training session on the learning of the Morris water maze task. The results are reported as mean \pm SEM latency (A) or distance $(B)$ the animals traveled from the starting point to the submersed platform. The test trials were performed $48 \mathrm{~h}$ after the training trials. The $\mathrm{X}$-axis represents the starting position for each trial. Two-way ANOVA showed a significant decrease in the scores as a function of the number of trials $(P \leq 0.05)$ but no significant effect of treatment either on the training or on the retention (test session) scores.

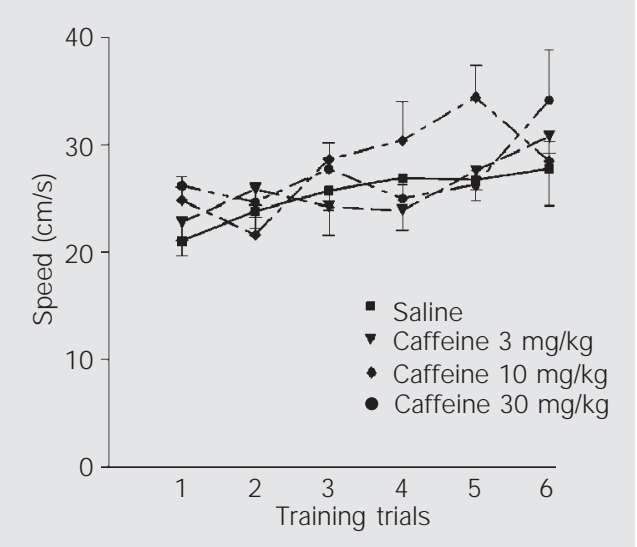

Figure 2. Effect of the administration of caffeine $30 \mathrm{~min}$ before the training session on swimming speed during the Morris water maze training trials. The results are reported as mean \pm SEM . Two-way ANOVA showed a significant decrease in the scores as a function of the number of trials $(P \leq 0.05)$ but no significant effect of treatment either on the training or on the retention (test session) scores. The same analysis also showed a significant $(P \leq 0.05)$ interaction between the treatment and the repeated measure (trials). 
tency to reach the platform $(\mathrm{P} \geq 0.2)$. In the test session the animals continued to decrease their scores $(\mathrm{P} \leq 0.001)$. The pre-test caffeine treatment did not affect the individual retention $(\mathrm{P}=0.13)$. On the other hand, the "shape" of the retention curve in the test session showed that caffeine, particularly at the lower doses, tended to improve memory retrieval: interaction treatment $v s$ repeated measure, traveled distance: $\mathrm{P} \leq 0.05$, latency: $\mathrm{P} \geq 0.2$.

\section{Discussion}

The data presented above agree with previous studies on humans suggesting an improving effect of caffeine on memory (3-7) and show that the Morris water maze task is a good model for the study of this effect. Our results also agree with most of the previous studies reporting improving effects of caffeine in animal models of learning and memory. Molinengo et al. (12) reported re-
Figure 3. Effect of the administration of caffeine immediately after the training session on the learning of the Morris water maze task. The results are reported as mean latency (A) or distance (B) the animals traveled from the starting point to the submersed platform. The test trials were performed $48 \mathrm{~h}$ after the training trials. The X-axis represents the starting position for each trial. $* P \leq 0.05$ and $* * P \leq 0.01$ compared to control (Duncan test after two-way ANOVA related to test scores).
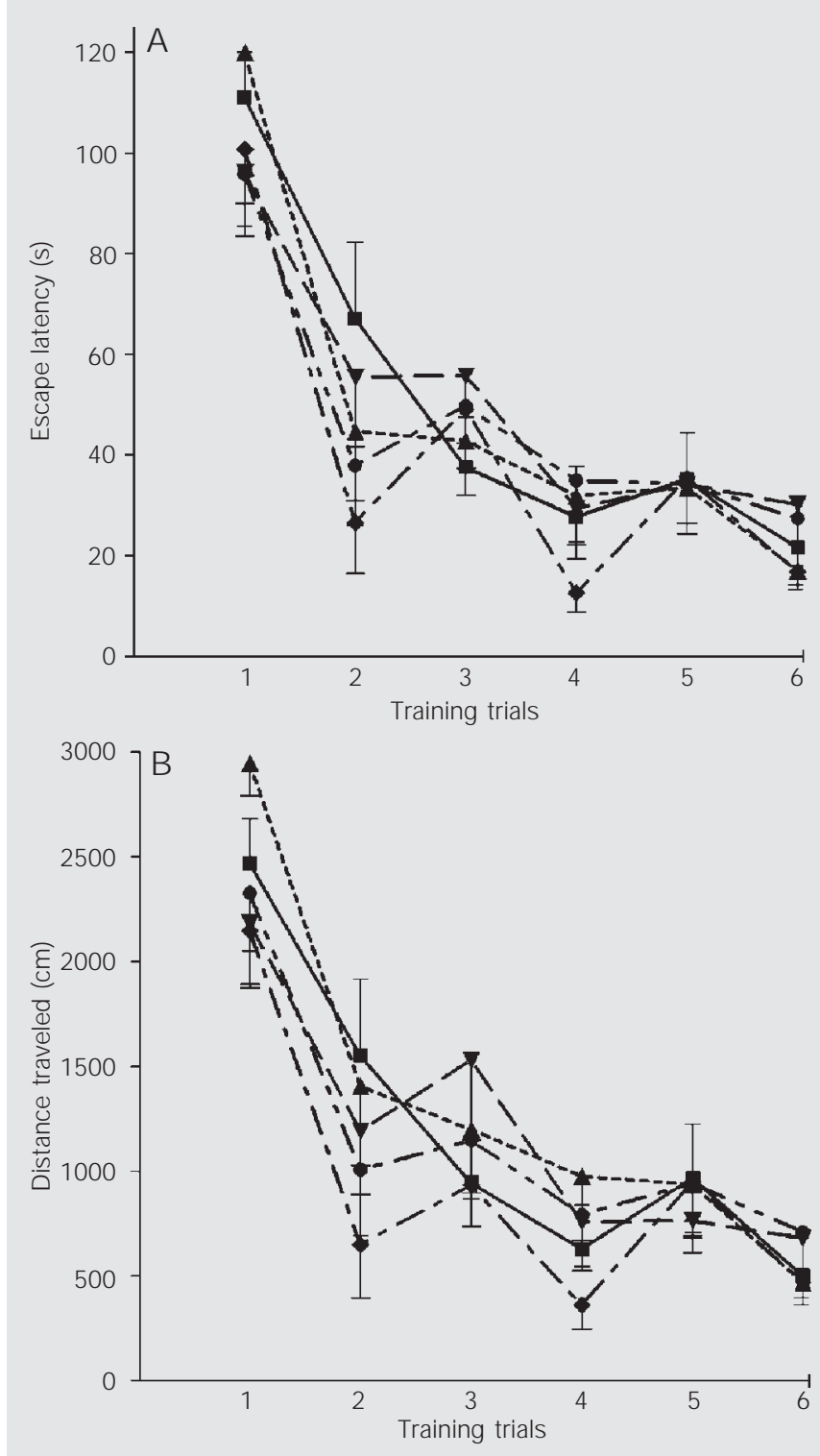

- Saline

\Caffeine $0.3 \mathrm{mg} / \mathrm{kg}^{* *}$ - Caffeine $3 \mathrm{mg} / \mathrm{kg}^{*}$

- Caffeine 10 mg/kg*

- Caffeine 30 mg/kg

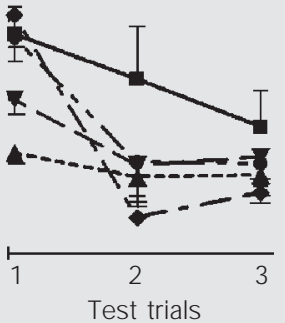

Test trials

Saline

ACaffeine $0.3 \mathrm{mg} / \mathrm{kg}^{*}$

Caffeine $3 \mathrm{mg} / \mathrm{kg}$

- Caffeine 10 mg/kg

- Caffeine 30 mg/kg

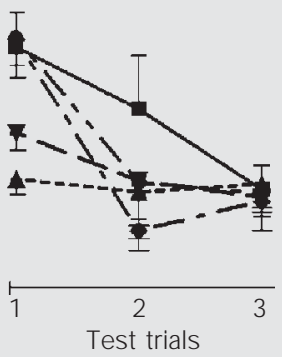


duction in memory decay in rats receiving chronic administration of caffeine after interruption of training in the staircase task. There are also some reports of caffeine improving memory consolidation when administered after training for a habituation task in rats (10), inhibitory avoidance in mice (13) and in rats (10), a multi-chamber maze in mice (14), and active avoidance in rats $(15,16)$.

The present results stress some particularities of the memory-improving effect of caffeine that were not systematically addressed in previous studies: 1) the effect of caffeine was more evident when the drug is administered after training, suggesting an effect on memory consolidation, 2) caffeine was ineffective when administered before training, suggesting that it does not affect working memory and memory acquisition, at least in the Morris water maze task, 3) the mild but significant effect of pre-testing caffeine administration suggests that it can improve memory retrieval, and 4) the effect of

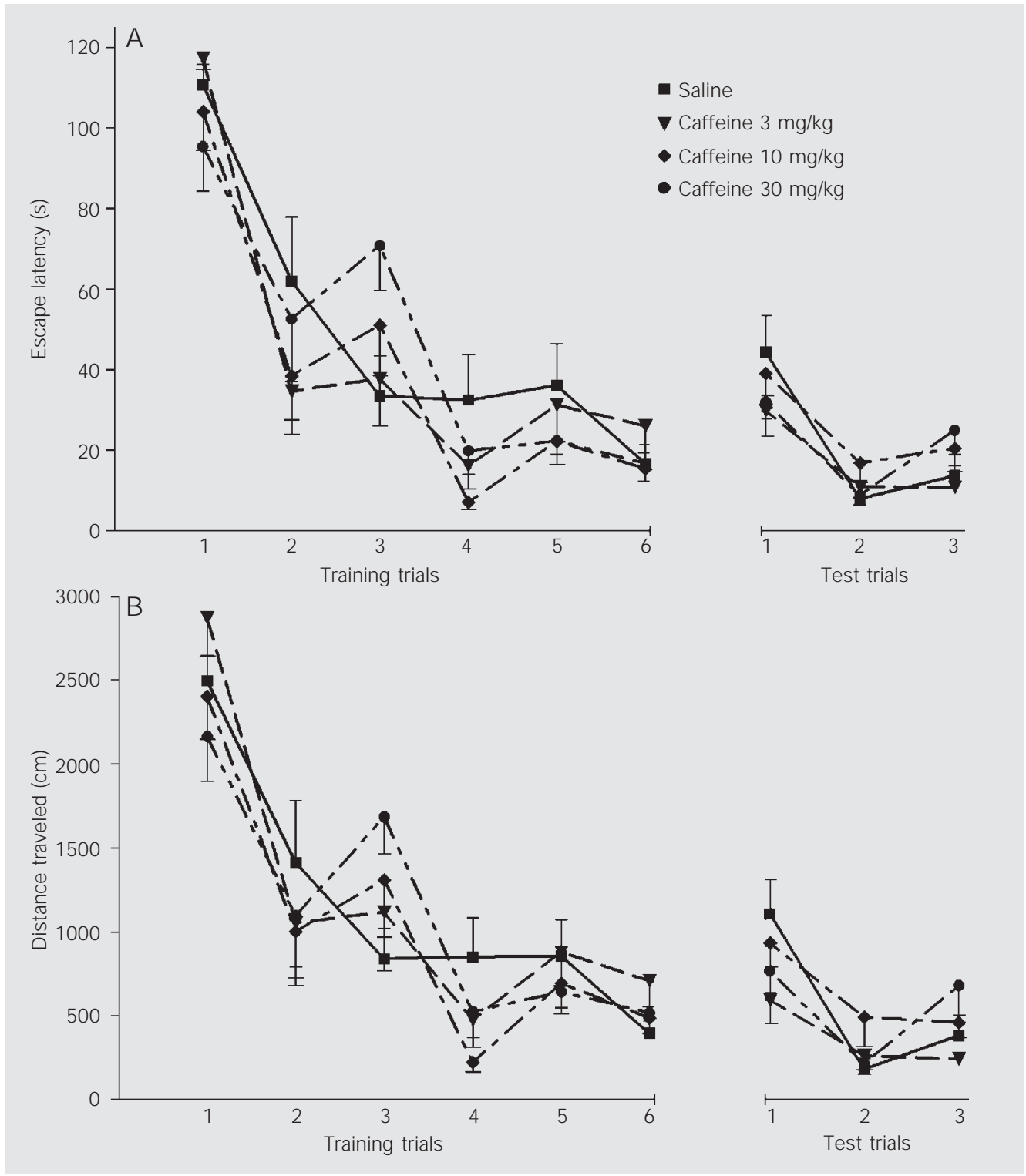

Figure 4. Effect of the administration of caffeine 30 min before the test session on the learning of the Morris water maze task The results are reported as mean \pm SEM latency $(A)$ or distance (B) the animals traveled from the starting point to the submersed platform. The test trials were performed $48 \mathrm{~h}$ after the training trials. The X-axis represents the starting position for each trial. Two-way ANOVA of the test data showed a significant interaction between the caffeine treatment and the repeated measure in relation to the distance scores $(P \leq 0.05)$ but not in relation to latency scores. No significant effect of treatment on individual retention scores was observed. 
caffeine was observed after the administration of lower but not higher doses.

The effect of post-training caffeine administration on memory consolidation cannot be attributed to a direct influence on performance since the drug was effective only when administered after training, and the test session occurred only $48 \mathrm{~h}$ later. Caffeine $(10 \mathrm{mg} / \mathrm{kg})$ caused a positive interaction with the increase observed in swimming speed as a function of the trials, but, again, it was not the situation in which caffeine improved memory: caffeine improved memory when administered after all the training trials and presented the highest effects with the lower doses that did not improve swimming speed.

Most of the previous animal studies have reported that post-training caffeine administration improved memory retention (13, 14,17). Just like in the present investigation, previous studies reported that pre-training caffeine administration was ineffective or even impaired memory retention in animals (18-20). The same occurred in human studies in which pre-training caffeine administration was ineffective $(7,21)$ or even impaired memory storage $(22,23)$. Contrary to our results, the animal studies of Roussinov and Yonkov (24) and Yonkov and Roussinov (14) reported an improving effect of caffeine when administered before the training session. However, in those studies caffeine was administered ip 5 min before training and most probably was available in effective plasma concentrations only after the training session.

To our knowledge, the literature contains few reports of the effect of caffeine on memory retrieval, a subject that clearly deserves further investigation. The results obtained in those studies agree with our results, suggesting that caffeine improves memory retrieval. The improving effect of caffeine on retrieval observed in this study was mild but it should be considered in view of the consistency of this observation with the other studies reporting the same effect. In a previous study we showed that caffeine improves retrieval in inhibitory avoidance and habituation tests (10). Valzelli et al. (25) reported that caffeine improved memory recall of poor learning mice. Riedel et al. (4) reported that caffeine attenuated the scopolamineinduced impairment of free recall from shortand long-term memory and of quality and speed of retrieval from long-term memory in a word learning task in humans.

Our results showed that only lower doses of caffeine improved retention in the Morris water maze task. Most of the previous animal studies showed an improving effect on memory retention with low doses of caffeine ranging from 0.2 to $20 \mathrm{mg} / \mathrm{kg}$ administered to rats and mice $(13,14,17,24)$. However, the diversity of memory tasks and the few studies reported in the literature are not enough to permit comparisons with our data, especially if we consider the lack of studies with higher doses. This effect may result from the interaction of caffeine with more than one cell target.

The dual effect of caffeine, causing memory improvement at lower doses and memory impairment or no effect at higher doses, may be reflecting the action of caffeine on more than one type of receptor. Caffeine is an antagonist of both $\mathrm{A}_{1}$ and $\mathrm{A}_{2}$ adenosine receptors (26). There is controversy about the mechanism that mediates the memory-improving effect of caffeine. Adenosine $A_{1}$ receptors are expressed densely in the cerebral cortex and hippocampus $(27,28)$. Activation of adenosine $\mathrm{A}_{1}$ receptors strongly inhibits the release of acetylcholine from pyramidal hippocampal neurons (29-31). Acetylcholine has been shown to be important for memory storage (32). Based on this and on the fact that elderly people present a progressive decline in brain acetylcholine level and are more susceptible to the beneficial effects of caffeine on memory, some authors consider the inhibition of the $A_{1}$ adenosine receptors to be the main mechan- 
ism explaining the effect of caffeine on memory (3). On the other hand, others suggest that the improving effect of caffeine on memory cannot be explained by its action as an adenosine $A_{1}$ receptor antagonist. They argue that adenosine $A_{1}$ receptor agonists, like N6-(R-phenylisopropyl)adenosine (12) or N6-cyclopentyladenosine (33), do not affect the memory-improving effect of caffeine and can even increase it under certain circumstances. They also show that the $\mathrm{A}_{1}$ receptor antagonist, 3-dipropylxanthine, does not improve memory retention (33). According to this evidence, the behavioral stimulant effects of methylxanthines would be more properly explained by their action as adenosine $\mathrm{A}_{2}$ receptor antagonists (1). The adenosine $\mathrm{A}_{2 \mathrm{~A}}$ receptors are predominantly expressed in the striatum (34). We showed that caffeine can reverse the memory impairment of striatal dopamine-depleted rats (15).

The present investigation shows that caffeine improves memory consolidation and suggests that it can also improve memory retrieval in a task specific for the spatial/ relational memory system that models the human hippocampal memory system.

\section{References}

1. Howell LL, Coffin VL \& Spealman RD (1997). Behavioral and physiological effects of xanthines in nonhuman primates. Psychopharmacology, 129: 1-14.

2. Griffiths RR \& Woodson PP (1988). Reinforcing properties of caffeine: Studies in humans and laboratory animals. Pharmacology, Biochemistry and Behavior, 29: 419-427.

3. Riedel WJ \& J olles J (1996). Cognition enhancers in age-related cognitive decline. Drugs and Aging, 8: 245-274.

4. Riedel W, Hogervorst E, Leboux R, Verhey F, van Praag H \& J olles J (1995). Caffeine attenuates scopolamine-induced memory impairment in humans. Psychopharmacology, 122: 158-168.

5. Calev A (1994). Neuropsychology and ECT: Past and future research trends. Psychopharmacology Bulletin, 30: 461-469.

6. Pollina DA \& Calev A (1997). Amnesia associated with electroconvulsive therapy - progress in pharmacological prevention and treatment. CNS Drugs, 7: 381387.

7. Smith A, Maben A \& Brockman P (1994). Effects of evening meals and caffeine on cognitive performance, mood and cardiovascular functioning. Appetite, 22: 57-65.

8. Paré W (1961). The effect of caffeine and seconal on a visual discrimination task. J ournal of Comparative Physiology, 54: 506-509.

9. Rahmann H (1963). Einfluss von Koffein auf das Gedächtnis und das Verhalten von Goldhamstern. Pflügers Archiv. European J oumal of Physiology, 276: 384-397.

10. Angelucci MEM, Vital MAF, Cesário $C$,
Zadusky CR, Rosalen P \& Da Cunha C (1999). The effect of caffeine on animal models of learning and memory. European J ournal of Pharmacology, 373: 135140.

11. Morris RGM, Garrud P, Rawlins J NP \& O'Keefe J (1982). Place navigation impaired in rats with hippocampal lesions. Nature, 297: 681-683.

12. Molinengo $\mathrm{L}$, Scordo I \& Pastorello $B$ (1994). Action of caffeine, L-PIA and their combination on memory retention in the rat. Life Sciences, 54: 1247-1250.

13. Cestari V \& Castellano C (1996). Caffeine and cocaine interaction on memory consolidation in mice. Archives Internationales de Pharmacodynamie et de Therapie, 331: 94-104.

14. Yonkov DI \& Roussinov KS (1983). Influence of eserine on the learning and memory facilitating effect of central stimulants. Acta Physiologica et Pharmacologica Bulgarica, 9: 11-17.

15. Gevaerd MS, Takahashi RN, Silveira R \& Da Cunha C (2001). Caffeine reverses the memory disruption induced by intra-nigral MPTP-injection in rats. Brain Research Bulletin, 55: 101-106.

16. Yonkov DI (1984). Possible role of brain dopaminergic systems in the memory effects of central stimulants. Methods and Findings in Experimental and Clinical Pharmacology, 6: 235-239.

17. Yonkov DI (1985). Correlations between the effects of CNS stimulants on memory processes and open field behavior of rats: the importance of brain cholinergic activity. Methods and Findings in Experimen- tal and Clinical Pharmacology, 7: 113-118.

18. Furusawa K (1991). Drug effects on cognitive function in mice determined by the non-matching to sample task using a 4arm maze. Japanese J ournal of Pharmacology, 56: 483-493.

19. Izquierdo J A, Costas SM, J ustel EA \& Rabiller $G$ (1979). Effect of caffeine on the memory of the mouse. Psychopharmacology, 61: 29-30.

20. Sansone $M$, Battaglia $M \&$ \& Castellano $C$ (1994). Effect of caffeine and nicotine on avoidance learning in mice: lack of interaction. J ournal of Pharmacy and Pharmacology, 46: 765-767.

21. Loke WH (1988). Effects of caffeine on mood and memory. Physiology and Behavior, 44: 367-372.

22. Erikson GC, Hager LB, Houseworth C, Dungan J , Petros T \& Beckwith BE (1985). The effects of caffeine on memory for word lists. Physiology and Behavior, 35: 47-51.

23. Terry WS \& Phifer B (1986). Caffeine and memory performance on the AVLT. J ournal of Clinical Psychology, 42: 860-863.

24. Roussinov KS \& Yonkov DI (1976). Cholinergic mechanisms in the learning and memory facilitating effect of caffeine. Acta Physiologica et Pharmacologica Bulgarica, 2: 61-68.

25. Valzelli L, Baiguerra G \& Giraud O (1986). Difference in learning and retention by Albino Swiss mice. Part III. Effect of some brain stimulants. Methods and Findings in Experimental and Clinical Pharmacology, 8: 337-341.

26. Bruns RF, Lu GH \& Pugsley TA (1986) 
Towards selective adenosine antagonists. In: Stefanovich V, Rudolphi K \& Shubert P (Editors), Adenosine: Receptors and Modulation of Cell Functions. Oxford University Press, New York, NY, USA, 51-58.

27. Bruns RF, Fergus J H, Badger EW, Bristol J A, Santay LA, Hartman J D, Hays SJ \& J uang CC (1987). Binding of the $A_{1}$-selective adenosine antagonist 8-cyclopentyl1,3-dipropylxanthine to rat brain membranes. Naunyn-Schmiedeberg's Archives of Pharmacology, 335: 59-63.

28. Mahan LC, McVittie LD, Smyk-Randall EM, Nakata H, Monsma J r FJ , Gerfen CR \& Sibley DR (1991). Cloning and expression of an $\mathrm{Al}$ adenosine receptor from rat brain. Molecular Pharmacology, 40: 1-7.

29. Briley M (1990). Biochemical strategies in the search for cognition enhancers. Pharmacopsychiatry, 2: 78-80.

30. Carter AJ, O'Connor WT, Carter MJ \& Ungerstedt U (1995). Caffeine enhances acetylcholine release in the hippocampus in vivo by a selective interaction with adenosine Al receptors. J ournal of Pharmacology and Experimental Therapeutics, 273: 637-642.

31. Morton RA \& Davies CH (1997). Regulation of muscarinic acetylcholine receptormediated synaptic responses by adenosine receptors in the rat hippocampus. J oumal of Physiology, 502: 75-90.
32. Everitt BJ \& Robbins TW (1997). Central cholinergic system and cognition. Annual Review of Psychology, 48: 649-684.

33. Von Lubitz DK, Paul IA, Bartus RT \& J acobson KA (1993). Effects of chronic administration of adenosine Al receptor agonist and antagonist on spatial learning and memory. European J ournal of Pharmacology, 249: 271-280.

34. Svenningsson $P$, Le Moine $C$, Fisone $G \&$ Fredholm BB (1999). Distribution, biochemistry and function of striatal adenosine $A(2 A)$ receptors. Progress in Neurobiology, 59: 355-396. 